\title{
REFLEKSI TEOLOGIS KEPASTIAN KESELAMATAN
}

\author{
Alon Mandimpu Nainggolan \\ Institut Agama Kristen Negeri Manado \\ Jalan Bougenville, Tateli Satu, Pineleng, Tateli Satu, Mandolang, Minahasa, Sulawesi Utara \\ Email: nainggolanalon1008@gmail.com
}

\begin{abstract}
ABSTRAK: Keselamatan adalah hal yang paling pokok dalam Alkitab dan kehidupan orang Kristen. Keselamatan mutlak menjadi kebutuhan, karena manusia telah jatuh ke dalam dosa baik secara perorangan maupun kolektif. Satu-satunya jalan agar manusia terbebas dari kebinasaan adalah melalui penerimaan Yesus sebagai Tuhan dan Juruselamat secara pribadi yang diikuti dengan hidup yang berorientasi pada kehendak-Nya. Yang diselamatkan oleh Tuhan Yesus, pastilah melakukan kehendak-Nya. Ketaatan kepada kehendak-Nya merupakan kasih karunia Tuhan bagi umat-Nya atau buah dari keselamatan yang telah dimiliki. Penelitian ini bertujuan untuk menyajikan refleksi teologi kepastian keselamatan dan signifikansinya bagi orang Kristen masa kini dalam memaknai keselamatan dan kepastian keselamatan. Penelitian ini dilaksanakan dengan berbasis kajian biblis, khususnya Matius 7:21-23 dan teologi sistematis seputarkepastian keselamatan. Melalui penelitian ini ditemukan teologi kepastian keselamatan dan pemahaman mengenai kepastian keselamatan berdampak positif bagi efektivitas dan produktivitas hidup orang Kristen di masa kini dan mendatang.
\end{abstract}

Kata Kunci: teologi; keselamatan; kepastian keselamatan; Matius 7:21-23

\section{THE THEOLOGICAL REFLECTION OF SALVATION ASSURANCE}

\begin{abstract}
Salvation is at the heart of the Bible and the Christian life. Salvation is absolutely a necessity because humans have fallen into sin both individually and collectively. The only way for humans to be free from destruction is through accepting Jesus as Lord and Savior, followed by a life oriented to His will. Those who are saved by the Lord Jesus must do His will. Obedience to His will is God's grace for His people or the fruit of salvation that has been possessed. This study aims to present a theological reflection on the certainty of salvation and its significance for Christians today in interpreting salvation and assurance of salvation. This research was conducted based on biblical analysis, especially on Matthew 7:2123 , and systematic theology around the certainty of salvation. This research found that the concept of biblical certainty of salvation and knowledge of the certainty of salvation positively impact the effectiveness and productivity of Christian life in the present and the future.
\end{abstract}

Keywords: theology; salvation; salvation assurance; matthew 7:21-23 


\section{PENDAHULUAN}

Pertanyaan tentang keselamatan (soteriologi) adalah pertanyaan utama di dalam Firman Tuhan. Pokok yang paling sakral di dalam Alkitab ialah perihal tentang keselamatan (Sproul, 2008, p. 211). Pemahaman keselamatan mempunyai peranan yang penting bagi dinamika kehidupan gereja (Chris, 2002, p. 5). Manusia mutlak membutuhkan keselamatan sejak kejatuhannya yang pertama (Adam) ke dalam dosa (bnd. Rm. 3:23; Rm. 6:23).

Peristiwa itu membuat semua orang untuk berusaha mencari dan memperoleh keselamatan. Secara objektif, Perjanjian Baru menegaskan bahwa Kristus adalah satu-satuNya Juruselamat: "Sebab di bawah kolong langit ini tidak ada nama lain yang diberikan kepada manusia yang oleh-Nya kita dapat diselamatkan" (Kis. 4:12; Janes, 2018, p. 82). Yesus sendiri menegaskan pula: "Akulah jalan... Tidak ada seorang pun yang dapat datang kepada Bapa, kalau tidak melalui Aku" (Yoh. 14:6). Orang Kristen percaya bahwa Yesus adalah satu-satunya Juruselamat karena Ia mengatakannya demikian. Apabila hal ini tidak benar, maka Ia bukanlah Juruselamat sama sekali, melainkan seorang pendusta, penghujat, dan seorang yang sangat bodoh, yang sangat angkuh (Kreeft \& Tacelli, 2006, p. 154). Orang Kristen meyakini hal tersebut.

Namun, permasalahannya adalah adanya perbedaan pandangan mengenai kepastian keselamatan. Ada yang mempunyai prinsip "sekali selamat tetap selamat" sehingga mereka tidak memerhatikan perbuatan mereka dalam kehidupan sehari-hari. Mereka mengaku percaya Kristus, namun dalam praktiknya kurang mendemonstrasikan gaya hidup sebagai seorang Kristen. Bagi sebagian pengikut ekstremis memandang bahwa kehidupan saleh setelah menjadi Kristen tidak terlalu penting. Kecenderungannya ditujukan kepada penganut aliran Calvinisme.

Ada juga yang berpandangan bahwa keselamatan itu bisa hilang. Karena, berpikir bahwa keselamatan itu bisa hilang, maka mereka mempunyai keraguan akan keselamatannya dan mereka selalu berusaha untuk mempertahankan keselamatannya itu dengan kekuatannya sendiri. Persepsi ini memahami keselamatan tergantung pada bagaimana keputusan akhir manusia. Maka sekalipun dia telah percaya kepada Yesus, ia tetap saja bisa tidak berhasil dalam memelihara dan mempertahankan keselamatannya. Dengan demikian, keselamatan itu dapat hilang kembali. Kecenderungannya diarahkan kepada penganut aliran Arminianisme.

Salah satu hal yang melatarbelakangi timbulnya perbedaan pandangan tentang soteriologi adalah karena adanya paradigma yang berbeda dalam melihat obyek keselamatan itu sendiri. Di satu pihak, lebih menekankan keselamatan dari sudut pandang peranan manusianya yang lebih dominan, dan di pihak lain penekanan keselamatan dari sudut pandang karya Allah secara mutlak (Janes, 2018, p. 85).

Itu sebabnya, kepastian keselamatan sangat mendesak dan signifikan untuk diketahui dan dimengerti oleh masing-masing orang Kristen supaya mereka dapat bertumbuh secara rohani dan memiliki kedewasaan rohani serta menjadi semakin serupa dengan Tuhan Yesus. Kepastian keselamatan menjadi sangat penting untuk diketahui dan dipahami karena Alkitab membahasnya di berbagai tempat. Tony Evans mengemukakan bahwa Allah tidak hanya memberikan orang percaya hidup kekal dalam Kristus, namun Dia juga memberi pengetahuan atau kepastian akan kehidupan kekal itu di dalam firman-Nya (Evans, 2005, p. 1-10).

Dari hasil observasi sehari-hari orang Kristen dapat dikelompokkan dalam tiga kelompok yaitu: Nampaknya ada beberapa orang yang telah percaya terhadap Yesus sebagai Tuhan dan Juruselamat secara pribadi, namun tidak memiliki keyakinan keselamatan. Di pihak lain, ada orang-orang yang memandang yakin keselamatannya, namun ia sesungguhnya belum 
diselamatkan. Akhirnya, ditemukan jenis keyakinan yang lain, yaitu orang percaya yang yakin akan keselamatannya. Salah satu nas yang membahas mengenai keselamatan adalah Matius 7:21-23. Dalam nas tersebut dikemukakan bahwa orang yang diselamatkan adalah yang melakukan kehendak Bapa di surga. Ketaatan kepada kehendak Bapa adalah kasih karunia Tuhan. Ketaatan kepada kehendak-Nya bukan syarat supaya diselamatkan, namun karena telah diselamatkan oleh kasih karuniaNya. Iman sejati akan melahirkan buah-buah pertobatan. Melalui penelitian ini akan ditemukan konsep keselamatan yang alkitabiah sehingga orang Kristen dapat hidup dan berkarya penuh makna sesuai dengan kehendak Tuhan.

\section{METODE}

Dalam penelitian dan penulisan artikel ini penulis memilih metode penelitian kualitatif yang bersifat deskriptif dan kajian biblis. Sugiyono menandaskan bahwa penekanan metode ini adalah pada proses daripada produk atau outcome, dan analisis data dilaksanakan secara induktif (Sugiyono, 2014, p. 9-10). Penulis melaksanakan studi dokumen/literatur terhadap Alkitab, buku pengantar dan teologi Sistematika, Ensklopedia Alkitab, Kamus Alkitab, Leksikon, jurnal, dan lain-lain yang adalah sumber dalam berteologi primer dan sekunder mengenai konsep kepastian keselamatan. Selanjutnya, penulis melakukan kajian biblis dengan analisis kesusastraan. Analisis kesusastraan menggali dan menyelidiki sejarah, penulis, sumber, ragam sastra, konteks kitab, dan lain-lain. Dalam pemakaian yang lebih sempit, analisis ini berfokus pada tujuan, struktur, ragam sastra, modus kitab atau bagian kitab tertentu (Sutanto, 2007, h. 290).

Penulis melakukan kajian biblis dengan membandingkan terjemahan teks dari berbagai bahasa (Yunani, Inggris, dan Indonesia) memperhatikan kepenulisannya (siapa, di mana dan kapan), meninjau tujuan, struktur, dan jenis sastra yang digunakan serta memberikan perhatian secara khusus pada bagian tertentu. Teks yang dikaji dalam penelitian ini adalah Matius 7: 21-23 untuk memahami kepastian keselamatan.

Pada tahapan berikutnya penulis menganalisis semua data yang telah terkumpul. Faktafakta, konsep-konsep dianalisis dan dimaknai dengan cara memperhatikan korelasi/keterkaitan, kesamaan/kemiripan, dan kerelevanan dengan topik yang dibahas (Nainggolan \& Labobar, 2020: p. 113-125). Hasil analisis disusun, didiskusikan dan dibuat signifikansinya bagi orang Kristen masa kini. Analisis data dilakukan secara induktif, melalui beberapa tahapan yaitu, reduksi data, penyajian data, verifikasi dan penarikan kesimpulan (Sugiyono, 2014, p. 339-343).

\section{HASIL DAN PEMBAHASAN}

\section{Keselamatan dalam Alkitab}

Kata asli selamat/keselamatan adalah yesyu'a (Ibrani) dan soteria (Yunani) yang merujuk pada pembebasan atau pemeliharaan dari bahaya atau penyakit (Douglas, 2004, p. 375). Pengertian lain adalah suatu keadaan yang menunjukkan relasi yang baik antar sesama, dunia (kosmis) dan Allah. Tentu yang mendasar adalah hubungan dengan Allah (Groenen, 1988, p. 52). Baik Alkitab dalam PL maupun PB mencatat mengenai keselamatan, yang di dalamnya juga mencakup kepastian keselamatan.

Dalam kitab suci PL, Allah menyatakan diri sebagai Pembebas, yaitu YHWH, Allah yang memosisikan diri di pihak orang yang dianiaya sambil menjadikan urusan mereka urusan-Nya (Dister, 1999, p. 193). Contohnya, Tuhan membebaskan manusia dari apa saja yang membuatnya menderita sengsara secara lahiriah maupun batiniah yaitu dosa, penyakit, maut, ketakutan akan kuasa setan, kekuatiran 
akan masa depan, peperangan, perbudakan, penindasan, pembuangan (lih. Mzm. 130). Perjanjian Lama fokus pada pembebasan dari musuh dan hidup dalam kemakmuran. Pada bagian akhir Perjanjian Lama diperluas pada aspek berkat moral bahkan sampai pada unsurunsur yang melebihi batas-batas kebangsaan (Douglas, 2004, p. 1). Meskipun baik bangsa Israel maupun bangsa-bangsa lain tidak layak akan kegiatan pembebasan-Nya, namun Kristus mengabdikan diri sampai ke dalam kematian dan kubur untuk meneruskan pembebasan itu.

Ajaran Alkitab dalam Perjanjian Lama mengenai apa, mengapa dan bagaimana itu keselamatan mencapai klimaksnya pada gambar Hamba yang menderita (Yes. 53), ini merupakan nubuatan tentang penderitaan Tuhan Yesus yang akan terjadi. Khususnya di dalam Perjanjian Lama ada beberapa alat keselamatan yang disediakan Tuhan yaitu melalui para bapa leluhur, hakim-hakim, imam-imam, raja-raja, nabi-nabi dan pemberi hukum.

Dalam Perjanjian Lama keselamatan di dalam Allah adalah pasti. Hal ini bisa dibuktikan dengan digenapinya janji-janji Allah kepada umat pilihan-Nya. Misalnya, janji Allah untuk melepaskan bangsa Israel yang adalah umat pilihan-Nya dari perbudakan bangsa Mesir memang terjadi, janji Allah untuk memberikan tanah Kanaan kepada bangsa Israel memang terjadi. Hal ini mengindikasikan bahwa di dalam Allah keselamatan itu adalah pasti. Sebab Allah adalah pribadi yang setia menggenapi janji-janji-Nya (Bil. 23:19).

Dalam Kitab Perjanjian Baru menunjukkan bahwa melalui Yesus orang Nazaret, Allah bertindak membebaskan manusia dari dosa, dari kuasa yang jahat dan maut. Sentralnya adalah Yesus Kristus (Yoh. 3:16). Pusat keselamatan itu adalah salib Kristus (Rm. 1:16; 1 Kor. 1:18), dengan tetap terkait dengan kebangkitan Kristus. Dalam kematian Kristuslah Allah melaksanakan tindakan penyelamatan yang utama bagi manusia.
Keselamatan di dalam Allah melalui Yesus Kristus adalah pasti. Di mana atas inisiatif Allah maka Ia menganugerahkan anakNya yang tunggal, yaitu Tuhan Yesus Kristus agar orang-orang yang percaya kepada-Nya memperoleh keselamatan (Yoh. 3:16). Keselamatan dan kepastian keselamatan adalah dua hal yang saling berhubungan erat. Paradigma orang terhadap keselamatan akan memengaruhi cara pandangnya tentang kepastian keselamatan. Jikalau keselamatan itu adalah anugerah Allah semata di dalam dan melalui Tuhan Yesus Kristus, maka keselamatan adalah pasti. Namun, jikalau keselamatan adalah atas usaha manusia atau atas kerja sama antara manusia dengan Allah, maka keselamatan itu tidaklah pasti/bisa hilang.

\section{Analisa Matius 7:21-23 dan Teologi Kepastian Keselamatan}

Di bawah ini penulis menguraikan tentang latar belakang kitab Matius, analisis konteks, analisis teks Matius 7:21-23 dan signifikansinya bagi orang Kristen masa kini.

\section{Analisis Latar Belakang}

Tidak ada kesepahaman mengenai siapa yang menulis kitab Injil ini, namun menurut suatu tradisi Gereja abad mula-mula, penulisnya adalah Matius, salah seorang dari kedua belas murid Tuhan Yesus (Marxsen, 2003, p. 183; Tenney, 2009, p. xix). Matius adalah seorang saksi mata kehidupan Yesus, yang menyertai-Nya mulai dari Ia dibaptis sampai kepada hari Ia terangkat ke surga (bnd. Kis. 1:21-22). Ada dua pendapat tentang waktu penulisan kitab Injil Matius ini, yang pertama pada periode tahun 80-100 M (sesuai dengan pandangan kebanyakan ahli). Yang kedua, diperkirakan pra-70 M, bahkan bisa jadi 40-60 M (Drane, 2003, p. 220). Mengingat Matius mengambil sumber dari Markus yang ditulis sekitar tahun 55-65 M, maka kemungkinan besar Injil Matius ditulis setelah itu, yakni sekitar tahun 66-70 M. 
Kitab ini berisi kisah dari saksi mata mengenai Kristus agar pembaca percaya bahwa Dia adalah Mesias, Anak Allah, sesuai dengan isi Perjanjian Lama (Alkitab Penuntun Hidup Berkelimpahan, 2006, p. 1496). Injil ini perama-tama ditujukan kepada orang Yahudi karena Injil ini merupakan Injil yang mencolok ke-Yahudian-nya. Salah satu yang menguatkan pernyataan ini adalah beberapa peribahasa masih menyatakan bahwa Injil ini memiliki "paradigma Yahudi", misalnya, selalu mempergunakan terminologi "Kerajaan Surga" untuk menggantikan "Kerajaan Allah" (Mat. $3: 2 ; 4: 17 ; 7: 21-23)$. Latar belakangnya ialah keseganan untuk menyebutkan nama Allah, mengingat hukum Taurat yang ketiga. Itulah sebabnya "Allah" diganti dengan tempat Allah bersemayam "sorga". (Duyverman, 2000, p. 53). Mungkin terminologi "sorga" dipilih dan dipakai sebagai ungkapan pengganti terhadap "Allah" berdasarkan penghormatan khas Yahudi yang enggan menyebut/memanggil nama Tuhan (Kel. 20:7; Mat. 5-7; Donald, 1993, p. 22).

Bagi orang Yahudi yang saleh kata "Allah" terlalu suci digunakan dengan sembarangan dan terlalu sering. Namun, pada akhirnya Injil ini tidak hanya ditujukan kepada orang Yahudi saja, namun kepada bangsabangsa lain. Hal ini terlihat dari Amanat Agung yang dicatat dalam kitab injil Matius 28:19-20 (bnd. Kis. 1:8) bahwa murid Tuhan Yesus dan setiap orang percaya harus pergi, menjadikan murid, membaptis dan mengajar firman Tuhan kepada segala bangsa. Di samping itu, masih ada alasan yang lain bahwa kitab ini tidak hanya ditujukan pada orang Yahudi yaitu bahwa Yesus Kristus juga menolong, menyembuhkan orang yang tidak berasal dari orang Yahudi. Misalnya, Yesus Kristus menyembuhkan seorang perempuan Kanaan yang percaya (bnd. Mat. 15:21-28), Yesus menyembuhkan hamba seorang perwira di Kapernaum (Mat. 8:5-13).

Adapun ciri khas kitab ini yaitu, pertama, Injil ini merupakan Injil yang mencolok ke-
Yahudi-annya (J. Douglas, 2004, p. 38). Kedua, Pengajaran dan kehidupan pelayanan Tuhan Yesus Kristus di bidang penyembuhan dan pelepasan dipaparkan secara sistematis. Ketiga, kelima ajaran pokok berisikan materi yang terluas di dalam keempat kitab Injil yang menulis pengajaran Yesus, (1) selama pelayanan-Nya di Galilea dan (2) mengenai halhal terakhir (eskatologi). Keempat, Injil Matius ini secara khusus menyebutkan peristiwa dalam kehidupan Yesus Kristus sebagai penggenapan Perjanjian Lama jauh lebih banyak daripada kitab lain di Perjanjian Baru (Douglas, 2004, p. 38). Kelima, Kerajaan Sorga/Kerajaan Allah disebutkan dua kali lebih banyak dibandingkan dengan kitab lain di Alkitab Perjanjian Baru. Keenam, Matius menekankan: (1) standarstandar kebenaran dari Kerajaan Allah; (2) kuasa kerajaan itu atas dosa, penyakit, setansetan, dan bahkan kematian; dan (3) kejayaan kerajaan itu di masa depan dalam kemenangan yang absolut pada zaman akhir (Alkitab Penuntun Hidup Berkelimpahan, 2006, p. 1496).

Secara geografis Matius 7:21-23 merupakan bagian dari pengajaran/khotbah di bukit (Mat. 5-7). Dalam Injil Matius sering diadakan perbedaan antara pemberitaan Injil (Yun: kerussein to euanggelion) dan memberi pelajaran atau mengajar (Yun: didache). Memberitakan adalah memberitahukan kepada orang apa yang telah diperbuat oleh Allah bagi kita dalam kasih karunia--Nya yang sangat besar. Mengajar atau memberi pelajaran ialah terutama menguraikan apa yang dituntut Tuhan dari kita. Khotbah di bukit ialah pemberitaan dan pengajaran (J. Verkuyl, 2000, p. 3). Sebelum Tuhan Yesus naik ke bukit untuk mengajar dan berkhotbah Ia telah berkeliling di seluruh daerah Galilea, Ia memberikan pengajaran, memberitakan Injil, melenyapkan segala penyakit (Mat. 4:23-25). Kemudian karena ia melihat orang banyak berbondong-bondong mengikutinya maka Ia naik ke bukit untuk mengajar mereka. Menurut, Alkitab LAI Yesus 
Kristus berkhotbah dan mengajar di Galilea, tepatnya di sebuah bukit dekat kota Kapernaum. Ada beberapa alasan bahwa Yesus tampil di sebuah bukit dekat kota Kapernaum, pertama, karena sebelum Yesus naik ke bukit Ia sedang berkhotbah dan mengajar di Kapernaum (bnd. Mat. 4:15). Untuk memberikan kepada orang banyak apa yang mereka perlukan, naiklah Yesus Kristus ke atas bukit yang terkenal di Galilea di dekat kota Kapernaum. (Verkuyl, 2000, p. 9). Kedua, kota Kapernaum menjadi tempat orang-orang berkumpul setelah mendengar pengajaran-Nya. Karena di situlah Tuhan Yesus berdiam sejak ia menyingkir ke Galilea berhubungan dengan ditangkapnya Yohanes Pembaptis (Mat. 4:12). Mereka muncul dari daerah Galilea, Dekapolis, Yerusalem, Yudea dan seberang sungai Yordan. Ketiga, sebab khotbah di bukit tergolong dalam pelayanan Tuhan Yesus di tanah Galilea, maka logis memandang bahwa khotbah di bukit, disampaikan pada salah satu bukit yang mengelilingi tanah datar di utara. Karena tidak lama kemudian, setelah selesai pertemuan itu Tuhan Yesus Kristus tiba di wilayah Kapernaum (Mat. 8:5), maka diyakini tempat itu berada di sekitar daerah itu (Douglas, 2004, p. 38).

Galilea merupakan bagian utara Palestina. Suatu daerah sempit sepanjang $72 \mathrm{~km}$ (45 mil), di sebelah barat dataran tinggi Golan, dan tenggara Libanon (Browning, 2011, p. 113). Mata pencaharian mereka pada umumnya adalah pertanian, perikanan dan perdagangan (Douglas, 2004, p. 40). Galilea adalah wilayah bangsa-bangsa lain atau wilayah pelbagai bangsa (bnd. Mat 4:15) karena banyak bukan orang Yahudi tinggal disana. Jadi, ada kemungkinan Matius membayangkan ke depan misi gereja kepada orang-orang bukan Yahudi.

\section{Analisis Konteks}

Injil Matius dikatakan unik karena di dalamnya dimuat keseluruhan khotbah Yesus secara lengkap yang mengandung pernyataan
Mesianis. Khotbah-khotbah Yesus dalam Injil ini yang menjadikannya berbeda dari ketiga Injil lain, karena di dalamnya mengandung penekanan-penekanan, jangkauan dan gerakan Mesianis (Pfeiffer \& Harrison, 2008, p. 20). Penulisan khotbah ini memiliki maksud untuk memberikan pedoman kerohanian dalam kehidupan murid-murid Yesus pada saat itu sehubungan dengan keadaan mereka yang terpengaruh oleh praktik dan penafsiran yang salah dari orang-orang Yahudi dan para ahli Taurat.

Jika diselidiki lebih jauh, penulis dapat melihat hubungan pasal demi pasal dari kitab Matius ini. Khususnya Matius pasal lima sampai pasal tujuh yang merupakan rangkaian khotbah dan pengajaran Yesus Kristus di bukit. Pada Matius 7: 15-23, permasalahan utamanya tertuju pada orang-orang yang suka memanggil nama Tuhan, namun tidak melakukan kehendak Tuhan (Mat. 7:21), orang-orang yang suka mengadakan mujizat, mengusir setan, bernubuat namun motifnya tidak untuk memuliakan Tuhan (Mat. 7:22), mengaku percaya kepada Yesus Kristus namun tidak menghasilkan buahbuah nyata yang bersesuaian dengan pertobatan (Mat. 3:8), kemudian adanya nabi-nabi palsu yang tidak menghasilkan buah-buah yang nyata bersesuaian dengan imannya (Mat.7:16).

Dikemukakan dalam Lukas 6:43-46 bahwa orang yang telah percaya kepada Tuhan Yesus pasti mematuhi perintah-Nya dan menjauhi larangan-Nya. Dengan kata lain, orang yang diselamatkan pasti melaksanakan kehendak Tuhan. Karena orang baik akan menghasilkan apa yang baik dari kebaikan hatinya, namun orang jahat akan menghasilkan hal yang sebaliknya karena kejahatan hati mereka. Orang yang telah mengalami perubahan dan pembaharuan di dalam Yesus akan menghasilkan buah-buah sesuai dengan pertobatannya. Hidup orang Kristen adalah hidup yang dipimpin oleh Roh Kudus untuk menghasilkan buah-buah yang baik (Gal. 5:2223). 
Tuhan Yesus memberikan contoh atau ilustrasi tentang sebuah pohon yang dikenal dari buahnya supaya pendengar pada saat itu (orang dari Galilea, orang dari Dekapolis, dari Yerusalem, dari Yudea, dan dari seberang sungai Yordan) mengerti dan mampu memedakan antara nabi benar dan nabi palsu, antara orang percaya Yesus dengan orang yang tidak percaya kepada Yesus. Pada akhirnya mereka juga menjadi pelaku firman Tuhan. Ini bukanlah suatu kebetulan, namun ada alasannya yaitu baik orang Yahudi, Yunani dan Romawi sama-sama memakai gambaran, bahwa pohon dikenal melalui buahnya (Barclay, 1983, p. 472). Dalam bagian ini, Yesus Kristus memperingatkan mereka agar selalu waspada terhadap pengajaran yang bertentangan dengan Alkitab dan Ia memerintahkan agar pendengar pada saat itu selalu memerhatikan tindakan atau perbuatannya. Sebab, pohon dikenal dari buahnya dan manusia dikenal dari tindakannya. Pengajaran yang sesat dan pengajaran yang benar akan kelihatan dari buahnya.

Peringatan Yesus Kristus terhadap pendengar pada saat itu bertujuan untuk menghindari mereka dari pengaruh ajaran yang sesat yang bertentangan dengan kehendak Tuhan. Di samping itu, mau mengingatkan bahwa Yesus Kristus menghendaki semua orang yang percaya kepada-Nya tidak hanya menjadi pendengar firman Tuhan, namun harus menjadi pelaku firman Tuhan (bnd. Yak. 1:22). Tuhan menghendaki apa yang diajarkan dan dikhotbahkan oleh Tuhan Yesus dilakukan oleh para pendengar pada saat itu agar mereka disebut sebagai orang yang bijaksana, mendengar, mengerti menerapkan firman Tuhan dalam kehidupan sehari-hari atau dalam pelbagai dimensi hidup; Matius 7:24-27.

\section{Analisis Teks}

Matius 7:21-23 merupakan perbandingan yang bersifat perumpamaan antara orang munafik dengan murid benar. Yang mana orang munafik hanya mengakui Kristus sebagai
Tuhan dalam pengakuan verbal semata, sedangkan murid Kristus mengakui Kristus sebagai Tuhan dan Juruselamat, yang dibuktikan dengan melakukan kehendak-Nya. Contoh, orang yang munafik, melayani Tuhan dengan motivasi yang salah, memuliakan diri sendiri bukan memuliakan Tuhan, mencari popularitas, memperkaya diri sendiri, memasang tarif ketika melayani Tuhan (bisnis dengan memakai nama Yesus Kristus). Sedangkan, murid Kristus melayani untuk memuliakan Tuhan, melayani dengan menunjukkan keteladanan, mengabdikan diri kepada Tuhan, melakukan kehendakNya, dan lain-lain.

Mengaku bahwa diri beragama saja dengan tidak disertai perilaku hidup yang baik tidak akan membawa seseorang ke surga. Penghakiman yang dilakukan oleh Yesus akan berdasarkan perbuatan (Henry, 2014, pp. 318319).

Dalam ayat 21 Yesus Kristus mengatakan bahwa bukan setiap orang yang berseru kepada-Ku: Tuhan, Tuhan akan masuk ke dalam kerajaan sorga. Bisa juga menjadi seperti di bawah ini, misalnya,pertama, di antara orang-orang yang berseru kepada-Ku, "Tuhan, Tuhan" ada yang tidak masuk sorga. Kedua, tidak setiap orang yang mempunyai kebiasaan yang mengatakan bahwa Yesus ialah Tuhan akan diselamatkan. Ketiga, tidak setiap orang yang memiliki pengetahuan intelektual tentang Tuhan akan masuk sorga. Keempat, tidak setiap orang yang selalu atau terus berkata kepada-Ku "Tuhan, Tuhan" atau tidak setiap orang yang selalu atau terus menyebut nama$\mathrm{Ku}$ akan masuk sorga. Kelima, tidak cukup hanya memanggil-Ku "Tuhan, Tuhan" atau tidak setiap orang yang terus-menerus mengatakan bahwa Dialah Tuhanku akan masuk sorga. Keenam, menurut versi New International Version (NIV), "Not every one who says to me, Lord, Lord, will enter the kingdom of heaven." Artinya tidak setiap orang yang mengatakan Tuhan, Tuhan secara berulangulang kepada Aku (Tuhan) yang akan masuk 
kerajaan sorga. Ketujuh, yang tidak diselaatkan itu adalah orang yang tidak mengakui kemanusiaan Yesus Kristus, orang yang tidak mengakui keilahian Yesus Kristus, orang yang memiliki orientasi dan motivasi yang salah dalam melayani Tuhan, orang yang memandang Yesus Kristus hanya sebagai tuan, orang yang menganggap Yesus Kristus hanya sebagai guru/rabi, orang yang mengaku Yesus Kristus sebagai Tuhan akan tetapi ucapan di bibir berbeda dengan tindakan (terlibat dalam perdukunan, sihir, santet, tenung, dan lain-lain), orang yang menganggap pelayan Tuhan itu hanya sebagai profesi semata. Kata Kurios dapat diterjemahkan sebagai tuan. Seperti yang dimaksudkan oleh kepala tentara Romawi dalam Luk. 7:6. Kata ini diterjemahkan dari kata Ibrani ke Yunani, yang asal katanya adalah adonai yang berarti tuan.

Ayat 21 ini merupakan ayat yang menunjukkan bahwa kata-kata tidak dapat dijadikan pengganti perbuatan (LAI, TAMK, 2006, h. 77; Henry, 2014, p. 319). Tidak cukup hanya pengakuan verbal semata, namun iman harus diperlihatkan secara nyata dalam sikap hidup dan perbuatan. Sebab hanya ada satu jalan untuk membuktikan kesungguhan seseorang, yaitu melalui tindakan dan perbuatannya yang nyata. Iman tidak dapat dilihat kehadirannya melalui ucapan mulut semata-mata, namun akan terlihat nyata melalui sikap hidup dan perbuatan. Iman bukan semata-mata perasaan, namun suatu kepercayaan yang harus dipraktikkan dalam kehidupan sehari-hari, menit demi menit, maupun detik demi detik. "So, Whoever would be rated among the disciples, must take pains to devote himself sincerely and whole heart edly to the study of newness of life" (Calvin, 1972, p. 240). Jadi, yang diklasifikasikan sebagai murid Kristus, harus bersusah payah untuk mengabdikan dirinya dengan tulus dan dengan sepenuh hati belajar tentang hidup baru. Dengan kata lain, bahwa orang yang sudah diselamatkan harus melakukan kehendak Bapa di sorga, orang yang percaya kepada Kristus pasti melakukan apa yang diperkatakan oleh Tuhan Yesus Kristus (bnd. Luk. 6:46). Hal ini mungkin karena Roh Kudus telah bekerja di dalam hati orang tersebut. Namun, jika kesan batiniah tidak sesuai dengan ungkapan lahiriah, orang Kristen tidak lebih daripada gong yang berkumandang dan canang yang gemerincing. Ini bukan berarti bahwa orang Kristen tidak boleh berkata, Tuhan, Tuhan, atau dilarang berdoa dengan sungguh-sungguh, tidak boleh mengakui nama Yesus Kristus, atau tidak boleh mengakuinya dengan gamblang. Akan tetapi, yang dimaksudkan dalam konteks ialah agar tidak boleh mengandalkan hal-hal ini saja, atau mendemonstrasikan ibadah secara lahiriah saja tanpa kuasa di dalamnya (Henry, 2014, p. 319-320). Ibadah harus menyentuh dimensi lahiriah dan batiniah.

Kerajaan Sorga sama artinya dengan kerajaan Allah. Namun, BIS menerjemahkannya secara dinamis menjadi "akan memasuki dunia baru milik Allah" akan menjadi anggota umat Allah dan akan menikmati berkat pemerintahan Allah. Sorga di sini menunjuk kepada tempat orang-orang yang melakukan kehendak Bapa. Kata"but" (NIV), "melainkan" atau "tetapi” (BIS), menunjukkan perbandingan antara anak kalimat sebelumnya dan sesudahnya, "Only he who does the will of my Father who is in heaven," diterjemahkan hanya orang-orang yang melakukan kehendak Bapa$\mathrm{Ku}$ yang di sorga. Melakukan kehendak artinya melakukan apa yang diinginkan atau didambakan Allah untuk dilakukan. Inilah kehendakNya, yaitu agar manusia percaya kepada Kristus, agar manusia bertobat dari dosa, agar manusia menjalani hidup kudus, agar manusia saling mengasihi. Inilah kehendak Allah: pengudusan manusia yang percaya kepada-Nya (Henry, 2014, p. 320). Dengan kata lain, menjadikan Alkitab sebagai standar hidupnya. Bapa-Ku yang di sorga menunjuk kepada Allah. Mengatakan dan melakukan sesuatu merupakan dua hal yang berbeda dan sering 
kali juga terpisah, seperti orang-orang yang berkata, "Baik, bapa," namun ia tidak pergi (Mat. 21:30). Kesatuan antara kata dan perbuatan, keselarasan antara batiniah dan lahiriah, kesatuan ajaran dan percontohan hidup, integrasi antara teori dan praktik hidup menjadi amat penting.

Bagi Henry ayat 22 adalah sebuah upaya untuk menghindari malapetaka pada hari terakhir. Lebih jelasnya beliau mengemukakan bahwa seruan orang munafik terhadap ketatnya hukum ini, dengan menawarkan hal-hal lain sebagai pengganti ketidaktaatan (Henry, 2014, p. 320). Dalam ayat 22 dikatakan pada hari terakhir (lihat Yes. 2:11;17, Zak. 14:6), dalam BIS, diterjemahkan menjadi hari kiamat. Para ahli sebagian besar sependapat bahwa inilah arti sebenarnya, walaupun dalam bahasa Yunani hanya dikatakan "hari itu" dan NIV juga memakai kata "that day". Menurut Jamieson, "Thatday. What day? It is emphatically unnamed. But it is the day to which He had just referred, when men shall "enter" or "not enter" into in the kingdom of heaven. (see similar way of speaking of "that day" in 2 Tim 1:12; 6:8)" (Jamieson etall., 1990, p. 49). Namun, dapat juga diartikan sebagai hari kiamat atau hari penghakiman terakhir. Atau, bisa juga digunakan pada hari di mana Allah akan menghakimi dunia atau bila saatnya tiba Allah akan menghakimi semua orang. Hari di mana setiap manusia akan kelihatan apa adanya, ketika semua rahasia yang ada di dalam hatinya akan menjadi nyata, antara lain kemunafikan tersembunyi yang digunakan orang yang telah jatuh ke dalam dosa sekarang ini untuk menguatkan dan meneguhkan harapan mereka yang tidak berguna, sia-sia.

Bukankah kami bernubuat demi namaMu? Adalah terjemahan dari pertanyaan retoris yang mengharapkan jawaban "ya". Pertanyaan retoris tidak selalu bisa dipahami dengan mudah dalam beberapa bahasa. Contoh 'Tuhan, Tuhan', kami telah bernubuat demi nama-Mu. "Demi nama-Mu" diulang tiga kali dalam ayat ini. Pada umumnya ungkapan "dalam nama seseorang" mempunyai tiga arti (LAI, 2008, p. 77). Pertama, memohon kepada orang yang namanya disebut. Kedua, bertindak atau berbicara dengan kuasa atau wibawa orang yang namanya disebut. Ketiga, mengandalkan atau menyebutkan hubungan seseorang dengan orang yang namanya disebut itu. Sebagian besar terjemahan mengikuti arti yang kedua. Dengan demikian terjemahannya menjadi "dengan kekuasaan-Mu” atau sesuai dengan kuasa/ kemampuan yang Engkau berikan untuk melakukannya". Namun, hal ini dilakukan dengan motivasi yang salah, sehingga Yesus Kristus tidak mengenal mereka.

Bernubuat (prophesy dari NIV): sebagian besar penerjemah tetap menggunakan ungkapan bernubuat. Terjemahan BIS menggunakan menyampaikan pesan Allah. Dalam bahasa Yunaninya arti kata itu ialah menyampaikan wahyu dari Allah, tanpa menekankan peristiwaperistiwa yang akan datang. Namun, di samping itu dalam menerjemahkan bernubuat bisa juga memperhatikan mengenai "nabi" yang terdapat pada Matius 1:22. Kata kerja ini biasanya diterjemahkan menjadi menyampaikan pesan Allah atau memberitakan pesan dari Allah kepada orang-orang. Tentang ayat 22 Henry mengemukakan; bahwa kami bernubuat demi nama-Mu? Ya, bisa jadi seperti itu. Namun, Bileam dan Kayafas tidak diperkenankan bernubuat dan Saul tergolong nabi di luar kehendak Allah, akan tetapi semua ini tidak bisa membantu mereka. Mereka ini bernubuat demi nama-Nya, namun Dia tidak mengutus mereka. Mereka sekadar menggunakan dan memanfaatkan nama-Nya demi kepentingan mereka sendiri (Henry, 2014, p. 321).

Mengusir dalam bahasa Yunani kata kerja yang diterjemahkan mengandung arti mengeluarkan, biasanya dilakukan dengan paksaan.Lebih jelas lagi dengan memerhatikan kata Yunaninya yaitu ekballo artinya mengusir, mengeluarkan, menolak, mengirimkan, mem- 
awa ke luar. Dalam NIV memakai kata drive out demons, artinya mendorong keluar roh jahat/ setan (dalam arti jamak). Dalam Perjanjian Baru, kata kerja ini khusus digunakan untuk tindakan mengusir setan yang menguasai seseorang (sebagai contoh, perhatikan Matius 9:34; 10:1). Setan (NIV memakai kata demons) diterjemahkan oleh BIS menjadi roh-roh jahat. Sebelum menerjemahkan mengusir setan, bisa membaca dahulu penjelasan mengenai 'kerasukan" dalam Matius 4:24. Hal ini perlu, sebab setiap bahasa, mempunyai caranya sendiri di dalam melukiskan pengusiran setan. Mengusir bisa diterjemahkan menjadi "menghalau rohroh jahat dari diri manusia", membuang roh jahat yang menguasai manusia", atau membuat roh-roh jahat agar meninggalkan manusia. Penulis lebih tertarik mengatakan bahwa mengusir berarti mengeluarkan setan dengan paksaan dan tujuannya adalah agar manusia bebas dari kuasa roh-roh jahat/setan. Mengenai hal ini, Henry menandaskan bahwa demi nama-Mu kami telah mengusir setan? Bisa jadi memang demikian; Yudas mengusir setan, akan tetapi ia adalah orang yang ditetapkan untuk binasa. Origenes mengemukakan bahwa pada zamannya begitu penuh kuasanya nama Tuhan Yesus Kristus ketika digunakan untuk mengusir roh-roh jahat sampai-sampai orang Kristen yang fasik pun kadang-kadang ikut mempergunakan dan memanfaatkan nama itu demi kepentingannya. Seseorang dapat saja mengusir setan keluar dari manusia lain, namun dalam dirinya sendiri ada setan, atau lebih tepat lagi, malah dia sendirilah setannya (Henry, 2014, p. 321).

Mujizat (NIV memakai kata miracles). Dalam bahasa Yunani, ungkapan yang diterjemahkan menjadi mujizat menekankan aspek kuasa (lihat, penggunaannya dalam Matius 11:20). Mujizat atau keajaiban (BIS) dapat diterjemahkan menjadi "tindakan-tindakan besar" atau "tindakan-tindakan luar biasa". Atau menggunakan tindakan-tindakan besar yang menunjukkan kuasa Allah. Pada ayat 22 ini, dapat dikatakan bahwa walaupun mereka mampu bernubuat, mengusir setan, mengadakan mujizat, namun itu bukan untuk memuliakan Tuhan. Itu dilakukan dengan motivasi yang salah. Orientasinya bukan kepada Tuhan namun kepada diri sendiri. Hanya melaksanakan tindakan-tindakan yang luar biasa saja (bahkan yang adikodrati) belum tentu berasal dari Allah (Ul. 13:1-5; II Tes. 2: 8-12; Mat. 24:24) (Pfeiffer \& Harrison, 2008, p. 44). Sebagai perbandingannya, iblis juga bisa melakukan mujizat, menyembuhkan, hal-hal yang luar biasa dan menakjubkan, namun satu hal yang tidak dia lakukan yaitu iblis tidak melakukan kehendak Tuhan. Bisa saja ada keyakinan untuk melakukan mujizat, namun iman untuk membenarkan, meneguhkan tindakan itu tidak ada. Dalam rangka melakukan mujizat, perlu iman yang bekerja oleh kasih dan ketaatan kepada Tuhan. Karunia lidah, menyembuhkan dan lainnya bisa menjadikan orang diterima di dunia, namun hanya kesucian atau pengudusan sejatilah yang bisa diterima Allah. Kasih karunia dan kasih adalah jalan yang lebih utama dan pertama daripada memindahkan gunung, berkata-kata dengan semua bahasa manusia dan bahasa malaikat dan lainnya (bnd. 1 Kor. 13:1-2).

Pada ayat 23 dikatakan pada waktu itulah atau bisa juga diterjemahkan, kemudian (NIV memakai kata then). Namun BIS menerjemahkannya tetapi, karena ayat ini menunjukkan sikap Tuhan yang kontras atau bertentangan dengan sikap orang yang disebut ayat sebelumnya. Dalam kata-kata, Kristus tampaknya menyinggung kebanggaan orang-orang munafik, seolah-olah mereka berpikir bahwa pengakuan dengan bibir saja benar, seolah-olah melakukan segalanya dengan benar. Namun, Yesus Kristus akan bangun dan menjawabnya, bahwa profesi mereka adalah semua kosong dan tidak benar.

Aku akan berterus terang, adalah terjemahan dari kata kerja Yunani yang mengandung banyak arti. Arti, yang paling sering 
digunakan ialah "mengaku". Dalam kata aslinya omologeso berarti mengakui, mengatakan dengan terus terang. Dalam bagian ini kata kerja ini mempunyai arti dasar "berbicara secara terbuka dan terus terang". Dapat disimpulkan bahwa Tuhan berkata bahwa Aku akan memberikan penghakiman, Aku akan berbicara secara terang-terangan kepada mereka. Yesus Kristus akan berkata dengan terbuka atau secara langsung kepada mereka. Hal ini bisa disebut menunjukkan sikap tegas Tuhan. Aku tidak pernah mengenal kamu! (NIV, "I never knew you"). Kalimat ini bisa mengandung makna bahwa Tuhan tidak mempunyai urusan dengan mereka, Aku tidak pernah mengetahui kamu, kamu tidak pernah melayani Aku, Aku tidak mempunyai urusan apa-apa denganmu, atau kalian tidak ada artinya bagi-Ku. Never, that is, not a single moment. Just what does Jesus mean when he says, "never have I known you? There is a knowledge of the mind. That according to his divine nature Jesus possessed this knowledge in unlimited degree (Hendriksen, 1974, p. 377).

Secara harafiah pernyataan ini bisa diterjemahkan, tidak pernah itu adalah tidak ada waktu sekecil apapun. Yang Yesus maksudkan adalah Aku tidak pernah mengetahui kamu. Dalam hal ini ada pengetahuan dalam pikiran. Itu menurut sifat Ilahi Yesus yang memiliki tingkat tidak terbatas. Enyablah daripada-Ku bisa diterjemahkan dengan bahasa sehari-hari, seperti pergi dari sini. Namun menurut penulis, makna dari perkataan ini adalah sangat dalam yaitu mereka pergi dari hadapan Yesus Kristus sampai selama-lamanya. Yesus Kristus tidak memberikan pengampunan lagi kepada mereka sebab semuanya sudah terlambat. Dalam hal ini peranan Yesus Kristus dalam penghakiman itu ditunjukkan secara mengesankan karena disebut dengan jelas dan tanpa digugat (LAI, 2008, p. 77).

Pembuat kejahatan berasal dari bahasa Yunani yaitu anomia yang secara harafiah berarti yang melakukan kejahatan. Dalam Perjanjian
Lama, melakukan kejahatan berarti melakukan tindakan yang berlawanan dengan hukum Allah. Baik melalui tindakan, perkataan maupun pikiran. Meskipun demikian, dalam pandangan Matius "kejahatan" dinyatakan dengan kegagalan menunjukkan kasih terhadap sesama, sebab melalui kasih hukum Allah terpenuhi. Bisa diterjemahkan seperti ini Enyablah dari badapan-Ku! Apa yang kamu lakukan adalah yang menyakiti hati-Ku! atau pergilah dari hadapan-Ku, kamu yang cara bidupnya jabat itu atau kamu tidak bidup sesuai dengan kehendak. Allab; karena itu pergilah dari hadapan-Ku. Bisa juga Allah mengatakan seperti itu karena mereka tidak pernah melakukan apa yang diperintahkan Allah, atau apa yang mereka lakukan berlawanan dengan kehendak Allah. Apa yang mereka lakukan tidak sesuai dengan perintah Tuhan. Contoh kasus, di dalam Perjanjian Baru dikatakan adanya seorang Yahudi yang ahli mengusir setan, yang memakai nama Yesus dalam pekerjaan-Nya (Kis. 19:13). Untuk semuanya itu Yesus mengatakan, bahwa orangorang yang memakai nama-Nya untuk dasar dan alasan yang palsu, akan harus mempertanggungjawabkannya. Sebab tidak satu pun kepalsuan yang tersembunyi dari Tuhan, dan mereka akan dibinasakan di hadapan Allah. Seseorang tidak bisa menutupi kepalsuan selamanya, akan ada masanya itu akan terungkap. Yesus Kristus akan berkata, "I never knew you, depart from Me" (NIV). Artinya, dabulu Aku tidak pernab mengenalmu, enyablab dari badapan-Ku!. Notice that in vv. 21-23 Jesus presents himself as the judge at "the day", when his hearers would have expected God to be mentioned. The claimis all the more striking for being assumed, not argued. Moreover, the criterion of judgement is their relationship with him. For I never knew you as a formula of repudiation see also 25:12, and cf. Peter's denial, 26:70, 72, 74. Depart from me, you evil do ersis a quotation from Psalm 6:8, where it is the words of the pious sufferer to his persecutors. (France, 2007, 149). 


\section{Signifikansi bagi Pemaknaan Teologi Kepastian Keselamatan}

Dalam bagian ini penulis akan menjelaskan tentang konsep kepastian keselamatan yang Alkitabiah, pentingnya mengetahui kepastian keselamatan bagi orang Kristen.

\section{Konsep tentang Kepastian Keselamatan}

Yang menjadi sumber problematika dari dahulu sampai sekarang adalah adanya berbagai pandangan tentang kepastian keselamatan. Salah satu pandangan yang cukup ramai diperdebatkan adalah dengan adanya pandangan "sekali selamat tetap selamat". Di mana timbul pertanyaan-pertanyaan tajam seputar ini yaitu, setelah Allah memilih, memanggil dan menyelamatkan manusia apakah boleh bertindak sewenang-wenang/seenaknya sendiri dengan argumentasi bahwa keselamatan tidak dapat hilang? Pokok ini yang sering diserang dan dipertanyakan oleh banyak "teolog" nonreformed terhadap teologi reformed, karena mereka memandang bahwa ajaran "sekali selamat selamanya selamat/sekali selamat tetap selamat" menjadikan orang Kristen malas untuk berbuat baik. Seperti pada masa Marthin Luther mereka yang mengikutinya menjadi terlalu ekstrem. Artinya, mereka hanya mementingkan diselamatkan lewat iman, selanjutnya tidak lagi memandang penting perbuatan, bahkan mereka berani mabuk-mabukan, hidup tidak beres, percabulan, dan lain-lain. Zaman sekarang ini, era 4.0 atau 5.0, era digitalisasi banyak juga orang mengaku sebagai orang Kristen, akan tetapi masih terlibat dalam perdukunan, suap, perceraian, korupsi, serta melayani untuk memuliakan diri sendiri atau mencari popularitas semata (mengaku Kristen namun tidak menunjukkan gaya hidup seperti seorang yang sudah lahir baru).

Kemudian, dilanjutkan lagi dengan ajaran Yohanes Calvin yang mengajarkan bahwa keselamatan tidak bisa hilang. Dasar pemikirannya merujuk pada lima pokok Calvinisme, yang sering disingkat dengan TULIP:

1. Total Depravity, yaitu kerusakan yang total;

2. Unconditional Election, yaitu pemilihan yang tidak bersyarat;

3. Limited Atonement, yaitu penebusan yang dibatasi kepada orang pilihan;

4. Irresistible Grace, yaitu anugerah yang tidak dapat ditolak oleh manusia;

5. Perseverance of the Saints, yaitu ketekunan atau kesucian orang-orang kudus.

Banyak orang Kristen salah mengetahui dan mengerti selanjutnya segan untuk berbuat baik; berkata, berpikir dan bertindak benar karena yang penting telah menjadi Kristen berarti telah ada jaminan masuk sorga. Apakah memang demikian? Benarkah pandangan tersebut? Ada juga yang merasa diselamatkan dengan beberapa alasan seperti di bawah ini:

1. Karena mereka dilahirkan dalam keluarga Kristen.

2. Karena mereka sudah menjadi pengunjung setia gereja sejak kecil.

3. Karena mereka menjadi "orang-orang baik".

4. Karena mereka sudah menerima sakramen gereja yaitu Baptisan dan Perjamuan Kudus.

5. Karena mereka aktif dalam pelayanan di gereja, taat beribadah, guru sekolah minggu, pengurus pemuda, menjadi majelis gereja.

6. Karena mereka bisa mengusir setan, mereka bisa bernubuat demi nama Tuhan, mereka bisa mengadakan banyak mujizat, mereka bisa menyembuhkan berbagai penyakit.

7. Karena mereka memberi persembahan dan penyumbang untuk dana pelayanan gereja.

8. Karena mereka mampu mengajar firman Tuhan.

9. Karena mereka sering menyebut atau 
memanggil nama Tuhan.

Setelah penulis mempelajari topik ternyata untuk diselamatkan bukan sekadar telah melayani di sebuah gereja (menjadi seorang pelayan Tuhan), menyandang sebuah jabatan, setia dalam mengunjungi gereja pada hari Minggu. Namun, dalam Matius 7:21-23 dikatakan bahwa yang diselamatkan adalah orang yang melakukan kehendak Bapa di sorga. Dalam arti, mereka yang diselamatkan adalah mereka yang telah percaya kepada Tuhan Yesus sebagai Tuhan dan Juruselamat dan percaya dalam hatinya bahwa Allah yang telah membangkitkan-Nya dari antara orang mati (bnd. Rm. 10:9-10), serta hidup dalam persekutuan yang erat secara pribadi di sepanjang hidupnya dan menghasilkan buahbuah yang nyata sesuai dengan imannya. Berbuat baik bukan berarti supaya diselamatkan melainkan berbuat baik karena sudah diselamatkan. Perbuatan baik menjadi salah satu bukti kasih orang percaya kepada Tuhan Yesus dan sebagai ucapan syukur atas kasihNya yang sangat besar. Perbuatan baik bukan berarti syarat rahmat, melainkan sebagai akibat dan buah rahmat (Dister, 1999, p. 186). Perbuatan-perbuatan baik merupakan buah dari iman yang sejati (Enns, 2007, p. 107).

Barclay dalam tafsirannya mengatakan bahwa sangat penting untuk memerhatikan motivasi, perspektif, orientasi dalam mengikut atau pun melayani Tuhan Yesus. Apapun yang dilakukan, dikatakan, dipikirkan oleh setiap orang percaya seyogianya bertujuan untuk memuliakan Tuhan dan bukan untuk memuliakan diri sendiri. Dengan demikian, dapat tergenapi bahwa hidup bagi orang Kristen adalah hidup menurut kehendak Allah (Donald, 2008, p. 74h. 74; Sine \& Nainggolan, 2021:104-117).

Orang percaya tidak dapat menyembunyikan apapun dari Tuhan termasuk alasanalasan palsu untuk melayani Dia, sebab Ia maha tahu. Dalam bukunya Beingand Nothingness (Keadaan dan Ketiadaan), Sartre memasukkan suatu studi yang menarik mengenai kema- hatahuan Allah. Ia mengumpamakan Allah seperti seorang pengawas kosmis. Dari sorga, Allah melihat ke bawah dengan teliti dan mengawasi segala yang kita lakukan (Sproul, 2002, p. 66). Seperti dikatakan dalam 1 Samuel 16:7b, "Bukan yang dilihat manusia yang dilihat Allah, manusia melihat apa yang di depan mata, tetapi Tuhan melihat hati." Teks ini, mau menyatakan bahwa tidak ada yang tersembunyi bagi Tuhan.Tuhan mampu untuk melihat/ mengetahui hati manusia yang terdalam. Barclay menyatakan bahwa untuk semuanya itu Yesus mengatakan bahwa orang-orang yang memakai nama-Nya untuk dasar dan alasan yang palsu, akan harus mempertanggungjawabkannya. Kepalsuan orang-orang yang demikian itu akan ditelanjangi, dan mereka akan dibinasakan dari hadapan Allah (Barclay, 1983, p.472). Dalam bagian ini, penulis melihat pentingnya keselarasan antara iman dan perbuatan. Hanya ada satu jalan untuk membuktikan kesungguhan bahwa seseorang itu orang percaya, yaitu melalui tindakan dan perbuatannya yang nyata. Sebab, orang yang selamat akan melakukan kehendak Bapa di sorga (bnd. Luk. 6:43;45).

\section{Pentingnya Pengetahuan Kepastian Keselamatan}

Berdasarkan hal di atas dapat dikemukakan bahwa mengetahui tentang kepastian keselamatan bagi Kekristenan adalah suatu hal yang sangat penting dan mendasar. Mengapa? karena hal itu adalah salah satu doktrin yang sangat penting dan mampu untuk memotivasi pertumbuhan rohani setiap orang Kristen. Jikalau diperhatikan dan dipahami bahwa mulai dari Perjanjian Lama sampai kepada Perjanjian Baru selalu menunjuk pada karya penyelamatan Allah bagi manusia, dan yang menjadi puncak karya atau rencana penyelamatan Allah bagi manusia adalah ketika Ia mengaruniakan AnakNya yang tunggal yaitu Tuhan Yesus supaya setiap orang yang percaya kepada-Nya tidak binasa melainkan memperoleh hidup yang 
kekal (bnd. Yoh. 3:16).

Ada beberapa dampak yang ditimbulkan apabila seseorang sudah menerima atau mengalami keselamatan, akan terlihat hal-hal nyata sebagai berikut, pertama, menghilangkan keraguan ataupun ketakutan pada waktu menghadapi penghakiman yang akan datang. Bagi penulis, selama manusia hidup di dunia ini pasti akan mengalami keraguan. Hal ini dikarenakan oleh beberapa penyebab, misalnya: datangnya cobaan, permasalahan hidup yang begitu berat, sakit-penyakit, oleh karena rupa-rupa pengajaran, dll. Namun, sesungguhnya tidak seharusnya orang percaya mengalami keraguan lagi sebab Yesus sudah memberikan kepastian keselamatan kepada mereka (hal ini dinyatakan di dalam Alkitab). Tidak ada alasan untuk tidak memiliki hidup dalam sebuah kepastian sebab Tuhan sudah menjanjikan itu dalam firmanNya. Ketika kematian menjemput hendaknya orang Kristen tidak perlu takut lagi sebab sudah mengetahui bahwa ia telah diselamatkan oleh Yesus Kristus. Salah satu contoh tokoh Kristen yang sempat mengalami keraguan tentang kepastian keselamatan adalah Martin Luther, namun setelah membaca Alkitab, khususnya Roma 1:16-17 ia telah memiliki kepastian keselamatan.Menerima Yesus dan melakukan kehendak-Nya menghilangkan ketakutan dalam masa penghakiman.

Kedua, melabirkan antusiasme untuk memberitakan Injil kepada orang lain. Seseorang memiliki kerinduan atau antusiasme untuk memberitakan Injil kepada orang lain dipengaruhi sejauh mana ia yakin akan keselamatannya. Karena tidak mungkin seseorang bisa dengan berani untuk memberitakan Injil kepada orang lain jikalau dia sendiri tidak yakin dengan apa yang diberitakannya. Tidak satu pun yang mampu menghasilkan buah (bersaksi) tanpa tinggal di dalam Kristus (Yoh. 15:5). Kepastian keselamatan itu penting, sebab salah satu dari hal-hal yang patut dilakukan seorang pemberita Injil adalah menunjukkan jalan yang benar kepada orang lain. Sebab tidak mungkin "orang buta menuntun orang buta". Seorang pemberita Injil harus mengenal Yesus Kristus terlebih dahulu dan harus mengetahui jalan itu serta yakin bahwa ia sendiri telah diselamatkan melalui Yesus Kristus, kemudian ia melakukan pemberitaan Injil. Hal seperti ini lebih efektif dan efisien serta sesuai dengan pengajaran Yesus Kristus (Janes, 2018, p. 8588). Kata kuncinya adalah sebelum meyakinkan orang lain terlebih dabulu harus meyakinkan diri sendiri.

Ketiga, menstimulus orang Kristen untuk semakin bertumbuh dan mampu menghasilkan buah yang nyata dalam kehidupan sehari-hari.Yohanes 15:5 menyatakan bahwa orang percaya dapat berbuah, jikalau mereka tinggal di dalam Tuhan. Hal ini mengisyaratkan bahwa dengan kekuatan sendiri sesungguhnya manusia tidak dapat menghasilkan buah yang layak di hadapan Tuhan. Tanpa tinggal di dalam Tuhan manusia tidak dapat menghasilkan kebajikan sejati (iman yang benar, ketaatan kepada hukum Allah, motivasi yang benar dan tindakan yang benar). Hal ini dikarenakan sejak zaman dahulu kala manusia telah jatuh ke dalam dosa. Dalam hal inilah, penulis menyatakan bahwa keyakinan akan keselamatan dan persekutuan yang erat bersama Yesus Kristus sangat menentukan dan akan memengaruhi kehidupan orang Kristen tersebut. Semakin yakin bahwa Yesus adalah satusatunya jalan keselamatan maka akan semakin berpotensi bahwa ia akan menghasilkan buahbuah yang nyata dalam kehidupan sehari-hari. Sebab Tuhan Yesus mampu membawa perubahan bagi orang Kristen (dalam tindakan, perkataan dan cara pandang). Firman-Nya adalah kekuatan Allah yang menyelamatkan (Roma 1:16-17) dan yang mampu untuk mengajar, untuk menyatakan kesalahan, untuk memperbaiki kelakuan dan untuk mendidik dalam kebenaran (bnd. 2 Tim. 3:16).

Keempat, menstimulus orang Kristen lebih peduli terbadap kebutuban orang lain. Apabila orang Kristen memiliki relasi yang baik dengan 
Tuhan, maka sangat dimungkinkan bahwa dia juga akan berupaya dan berjuang untuk memiliki relasi yang baik dengan sesama (bnd. Kel. 17:1-20). Hal ini menjadi mungkin karena bukan diri sendiri lagi yang bertakhta dan memimpin dalam hati orang tersebut, namun Tuhan Yesus (bnd. Gal. 2:20). Sehingga sangat potensial relasi vertikal akan memengaruhi relasi horizontal. Pengenalan yang benar akan Allah akan memengaruhi paradigma seseorang terhadap sesama dan diri sendiri (bnd. Mat. 22:37-40). Hal ini didukung juga oleh firman Tuhan dalam Matius 25:40.

Kelima, melabirkan kerinduan dan komitmen untuk terlibat dalam pelayanan. Bagi penulis orang Kristen yang masih bayi secara rohani tidak akan tertarik untuk aktif dalam pelayanan. Sebab ia belum memiliki pemahaman dan pengenalan yang mendalam akan Allah. Orang yang tidak dewasa secara rohani tidak akan mampu untuk setia kepada pilihannya. Hal ini terjadi karena belum ada dasar atau fondasi iman yang kuat yang dimiliki oleh orang tersebut. Kesadaran untuk melayani orang lain akan tercipta apabila seseorang yakin akan keselamatannya dan bersedia untuk dipimpin oleh Roh Kudus serta adanya perjuangan yang optimal untuk mengikuti teladan Tuhan Yesus. Lihat, Markus 10:45. Dalam hal ini orang Kristen menyadari akan tiga tugas panggilan gereja yaitu bersekutu (koinonia), melayani (diakonia) dan bersaksi (marturia).

Keenam, melabirkan ketabahan dan sanggup bertahan dalam masa-masa sulit terutama bila harus menghadapi penganiayaan karena imannya (bnd. Mat. 10:28). Selama manusia berada di bumi ini maka tidak bisa dipungkiri bahwa tekanan, hambatan, gangguan, maupun penderitaan akan datang silih berganti. Hal ini perlu disadari agar setiap orang Kristen mampu menghadapi realitas hidup. Dengan demikian menjadi mampu sebagai pemenang dalam kesesakan dengan pertolongan Roh Kudus. Perlu diketahui, bahwa ada perbedaan antara orang percaya dengan orang yang tidak percaya kepada Tuhan Yesus ketika menghadapi penderitaan, yaitu di mana ketika orang Kristen mengalami penderitaan mereka memiliki Tuhan yang menyertai dan menolong sedangkan orang yang tidak percaya akan cenderung mengandalkan kekuatan sendiri dan mengandalkan sesamanya.

Ketujuh, melabirkan orang Kristen sebagai penatalayanan yang baik. Segala yang dimiliki oleh manusia (secara khusus orang Kristen) bukanlah miliknya sendiri, namun milik Tuhan. Mereka hanyalah sebagai penatalayanan. Mengapademikian? karena tidak ada seorang pun yang datang ke dunia ini dengan membawa apa-apa dan ketika sudah meninggal juga tidak akan membawa apa-apa (1:21). Kemampuan orang untuk menjadi seorang penatalayanan yang baik akan terwujud apabila ia menyadari bahwa semua yang dimilikinya adalah dari Tuhan. Demikianlah dapat dilihat relevansi yang erat antara hubungan orang percaya dengan Tuhan dan cara pandang orang tersebut terhadap apapun yang dimiliki di bumi ini.

Dengan memiliki kepastian keselamatan seorang yang percaya kepada Kristus akan selalu waspada dan berjaga-jaga terhadap segala godaan dan pengaruh dunia seperti ketamakan, kenikmatan daging dan hidup berfoya-foya, serta hidup yang tidak tertib (bnd. Gal. 5:19-20; Luk. 12:15). Orang yang sudah memiliki kepastian keselamatan tidak akan merasa nyaman ketika ia hidup di dalam dosa. Namun, orang tersebut akan berupaya dan berjuang secara optimal dengan pertolongan Roh Kudus untuk menjauhi dosa. Kecenderungannya bukan lagi melakukan dosa, namun tendensinya untuk memuliakan Tuhan dan berupaya secara optimal dengan pertolongan Roh Kudus untuk melakukan kehendak-Nya. Hal ini terjadi karena "dosa dan Roh Kudus tidak dapat mendiami tempat yang sama" (hal yang kotor dengan hal yang suci tidak dapat bersatu). Apabila dia mengalami kejatuhan ke dalam dosa, maka penulis meyakini bahwa ia akan 
segera mengaku dosa dan meninggalkan dosa tersebut serta berbalik kepada Tuhan.

Dengan memiliki kepastian keselamatan seorang percaya kepada Kristus akan bertobat dari dosa-dosanya, dan bertumbuh dalam kebenaran (Santoso, 2009, pp. 162-163). Orang yang sudah mengambil keputusan untuk percaya kepada Kristus, maka dengan pertolongan Roh Kudus dia akan berpaling dari dosa dan menghasilkan buah-buah yang nyata sesuai dengan imannya. Hal ini sesuai dengan apa dengan yang dikatakan oleh Yohanes Pembaptis di sungai Yordan (bnd. Mat. 3:8).

Kepastian keselamatan sangat penting untuk diketahui dan dipahami oleh setiap orang percaya supaya mereka dapat bertumbuh secara rohani dan memiliki kedewasaan rohani serta menjadi semakin serupa dengan Yesus Kristus. Menurut Evans, (2005, p. 148) bahwa berkat terbesar kepastian itu ialah karena ia membebaskan kita untuk menikmati dan bertumbuh dalam kehidupan Kristiani. Karena kepastian itu adalah buah ketekunan, maka tidak mungkin menghasilkan sikap hidup yang sembrono (Williamson, 2017, p. 206).

\section{KESIMPULAN}

Pandangan orang terhadap kepastian keselamatan berbeda-beda, disesuaikan dengan zaman, situasi, konteks mereka berteologi. Namun, berdasarkan Matius 7:21-23 keselamatan di dalam Yesus Kristus itu adalah pasti. Kepastian keselamatan itu ditandai dengan menghasilkan buah-buah yang nyata dalam kehidupannya. Mereka yang sudah diselamatkan merefleksikan Yesus Kristus di dalam kehidupannya yang nyata. Menghasilkan buah yang nyata (berbuat baik) bukan untuk

\section{DAFTAR RUJUKAN}

Barclay, W. (1983). Pemahaman Alkitab Setiap Hari. BPK Gunung Mulia.

Browning, W. R. F. (2011). Kamus Alkitab. Jakarta: BPK Gunung Mulia.

Calvin, J. (1972). Calvin's New Testament diselamatkan, melainkan karena sudah diselamatkan. Perbuatan baik hanyalah sebagai buah iman yang sejati. Sebab orang yang diselamatkan akan melakukan kehendak Bapa di sorga.

Kepastian keselamatan adalah anugerah Allah semata-mata, di dalam dan melalui Yesus Kristus, disambut dengan iman dan yang diwujudnyatakan dalam perbuatan. Ditopang oleh kehidupan rohani yang semakin progres dan dinamis, dan menghasilkan buah-buah kehidupan yang nyata. Semuanya bermuara kepada keagungan dan kemuliaan Allah Bapa di sorga.

Dalam rangka penelitian selanjutnya dengan topik yang sama disarankan untuk melakukan studi lapangan dengan metode kualitatif, kuantitatif, kombinasi, eksegese, hermeneutik, eksposisi dan lain-lain untuk mengggali relasi antara pemahaman teologi kepastian keselamatan dengan produktivitas hidup orang Kristen, pengaruh teologi kepastian keselamatan terhadap pertumbuhan iman orang percaya dan dampak teologi kepastian keselamatan terhadap motivasi pelayanan. Dapat juga menggunakan pendekatan kritik historis, naratif atau lainnya untuk membangun konsep teologi kepastian keselamatan menurut kitab Lukas dan lainnya. Melalui penelitian tentang refleksi teologi kepastian keselamatan ini diharapkan semakin banyak orang Kristen yang semakin berakar, bertumbuh dan berbuah ke arah Tuhan Yesus Kristus dan juga sebagai upaya penyadaran terhadap orang percaya supaya dapat menjadikan kehidupannya secara utuh sebagai arena wadah untuk memuliakan Allah tritunggal.

\section{Comentaries. Eerdmans.}

Chris, M. (2002). Doktrin Keselamatan dan Kebidupan Rohani. Iman Press.

Dister, S. N. (1999). Teologi Sistematika. Balai Pustaka.

Douglas, J. D. (2004). Ensklopedi Alkitab Masa 
Kini Jiid II. Yayasan Komunikasi BinaKasih/OMF.

Drane, J. (2003). Memahami Perjanjian Baru. Jakarta: BPK Gunung Mulia.

Duyverman, M. E. (2000). Perjanjian Baru. BPK Gunung Mulia.

Enns, P. (2007).The Moody Handbook Of Theology. Literatur SAAT.

Evans, T. (2005). Sungguh-sungguh Diselamatkan. Gospel Press.

France, R. T. (2007). The Tyndale New TestamentCommentaries. Momentum.

Guthrie, Donald (1993). Teologi Perjanjian Baru. BPK Gunung Mulia.

Groenen, C. (1988). Soteriologi Alkitabiah. Kanisius.

Hendriksen (1974). Matthew 1. The Banner of Truth Trust.

Jamieson, R., Fausset, A. R., \& Brown, D. (1990). A Commentary: Critical, experimental, and Practical on the Old and New Testaments (Mathew-John). Eerdmans.

Janes. (2018). Pemahaman Doktrin Soteriologi Terhadap Kegiatan Memberitakan Injil. PRUDENTLA: Jurnal Teologi Dan Pendidikan Kristiani, 1(1), 74-93. http://ejournal.sttbaptisjkt.ac.id/index.php/ prudentia.

Kreeft, P. \& Tacelli, R. K. (2006).Pedoman Apologetik Kristen 2. Kalam Hidup.

LAI (2006). Alkitab Penuntun bidup Berkelimpahan. Gandum Mas.
Marxsen, Willi (2003). Pengantar Perjanjian Baru. Gunung Mulia.

Matthew, H. (2014). Tafsiran MatthewHenry: Injil Matius 1-14. Momentum.

Nainggolan, A. M. \& Labobar,Y. F. (2021). Menggagas Penggunaan Benih dalam Perayaan Paskah: Analisis Biblikal Yohanes 12:20-26. Epigraphe: Jurnal Teologi dan Pelayanan Kristiani, 5(1), 113-125. http:/ /dx.doi.org/10.33991/ epigraphe.v5i1.239.

Pfeiffer, F. C.\&Harrison, E. F. (2008). Tafsiran Alkitab Wycliffe. Gandum Mas.

Santoso, A. (2009). The God Way: Handbook. Nusantara Books.

Sine, H., \& Nainggolan, A. M. (2021). Menelaah Kehendak Allah bagi Orang Percaya Berdasarkan Roma 12:2. Tumou Tou, 8(2), 104-117. https://doi.org/ $10.51667 /$ tt.v8i2.501

Sproul, R. C. (2002). Kebenaran-kebenaran Dasar Iman Kristen. Literatur Saat.

Sugiyono, (2014). Metode Penelitian Kuantitatif Kualitatif dan $\mathrm{R} \& D$. Alfabeta.

Sutanto, H. (2007). Hermeneutik Prinsip dan Metode Penafsiran Alkitab. Literatur SAAT.

Tenney, C. M. (2009). Survei Perjanjian. Gandum Mas.

Verkuyl, J. (2000). Khotbah di Bukit. BPK Gunung mulia.

Williamson, G. I. (2017). Pengakuan Iman Westminster. Momentum. 